\title{
Cultivating ethical dispositions in early childhood practice for an ethic of care: a contemplative approach
}

Book or Report Section

Accepted Version

Taggart, G. (2019) Cultivating ethical dispositions in early childhood practice for an ethic of care: a contemplative approach. In: Langton, R. (ed.) Theorizing Feminist Ethics of Care in Early Childhood Practice: Possibilities and Dangers. Bloomsbury, New York. ISBN 9781350067486 Available at http://centaur.reading.ac.uk/81380/

It is advisable to refer to the publisher's version if you intend to cite from the work. See Guidance on citing.

Published version at: https://www.bloomsbury.com/uk/theorizing-feminist-ethics-of-care-in-early-childhood-practice9781350067486/

Publisher: Bloomsbury

All outputs in CentAUR are protected by Intellectual Property Rights law, including copyright law. Copyright and IPR is retained by the creators or other copyright holders. Terms and conditions for use of this material are defined in 
the End User Agreement.

www.reading.ac.uk/centaur

\section{CentAUR}

Central Archive at the University of Reading

Reading's research outputs online 
(C) Geoff Taggart In Langford, R. (forthcoming) Theorising Feminist Ethics of Care in Early Childhood Practice: Possibilities and Dangers London: Bloomsbury

\section{Cultivating Ethical Dispositions in Early Childhood Practice for an Ethic of Care: a}

\section{Contemplative Approach}

\section{Introduction}

Langford et al (2017) argue that the care which practitioners in early childhood

education and care (ECEC) offer is far more than simply 'custodial'. For example, as part

of her research into 'professional love', Page (2015) observed the following take place:

Eva was asleep on a mattress on the floor. Rainee knelt down beside Eva. She bent right down to obtain eye contact. Rainee gently stroked the back of Eva's head while quietly calling, 'Hello' in a sing-songy voice. Eva reciprocated by lifting her head up, looked at Rainee, rocked back on to her knees, rubbed her eyes and moved her head from side to side before lying down again. Rainee lowered her head to maintain eye contact with Eva. Eva reached out for her teddy which was at the top of her mattress whilst Rainee continued to stroke Eva's head and talked to her until Eva was fully awake. Eva pointed to something on the other side of the room and Rainee said, 'What's that?' Eva got to her knees and then stood up. Rainee remained on her knees so that she maintained eye contact. Eva said 'Oh, Oh', which Rainee echoed followed by, 'I'm awake, I'm awake'. Eva appeared to be unsteady on her feet so Rainee, who was still kneeling, supported Eva by holding her hand. Eva sat down on Rainee's knee to drink a cup of milk, which was bought in by a practitioner. Rainee put her arm round Eva's back to support her whilst gently stroking Eva's leg. Rainee continued to talk in soft tones when responding to Eva's cues.

At first sight, such an episode would seem to be both touching and unremarkable, an indication of the kind of sensitive, empathetic responses of mothers to their children the world over. Yet there is no biological connection between the two and Renee is a preschool teacher. So where does her 'professional love' come from? In most parts of the world, the answer would be along the lines of 'maternal instinct' or 'feminine nurture', implying that (a) this work is restricted to fifty per cent of humanity and (b) such work is not a genuine profession since this capacity for caring, being instinctive, is not part of a discrete body of skills and knowledge. Moreover, since it is domestic and natural, such work is assumed to be part of the private realm of family rather than part of the public realm of professions. A step towards professionalisation could be taken by 
(C) Geoff Taggart In Langford, R. (forthcoming) Theorising Feminist Ethics of Care in Early Childhood Practice: Possibilities and Dangers London: Bloomsbury

asking, if not from gender or mothering experience, where this 'love' comes from. One answer is that our love, caring and empathy are expressions of our innate ethical nature as human beings. In this regard, feminist care ethics is useful since it articulates the connection between the kind of behaviours shown by Renee and the traditional questions of philosophical ethics such as 'what does it mean to be good?' The implication is that, if we can reconceptualise the capacity for love, caring and intimacy as ethical dispositions, the way is then open towards cultivating such dispositions in professional programmes. Of course, rooting a claim to professionalism in moral emotions may lead us to doubt whether higher education can provide a route to this professionalism, bearing in mind its traditional association with the refinement of logic and reason. The purpose of this paper is to argue that care ethics is part of an ongoing feminist challenge to a narrow kind of epistemology in higher education which separates mind from body and feeling from intellect. Care ethics imagines a self which is embodied and relational. Connecting this philosophical model with psychological research in attachment and moral development, I propose an experiential and contemplative approach to the ethical development of teachers in ECEC.

\section{Professional ethics and care ethics}

In previous work (Taggart 2011), I have contributed to the argument that, in order for ECEC to be taken seriously as a moral, non-gendered profession (akin to teaching, nursing, social work and ministry), the care which practitioners offer needs to be understood as a deliberately ethical undertaking, motivated by a socio-political concern to 'make a difference' (Dahlberg and Moss 2005 ; Fennimore 2014). Where activists in ECEC have so far attempted to address the ethical nature of the work, they have understandably sought to follow other aspiring professions by drawing up a code of ethics and providing materials by which practitioners can reflect on the extent to which 
(C) Geoff Taggart In Langford, R. (forthcoming) Theorising Feminist Ethics of Care in Early Childhood Practice: Possibilities and Dangers London: Bloomsbury

they embody principles in the code (e.g. Feeney and Freeman 2018). As part of this model, trainee practitioners are typically asked to consider particular ethical dilemmas and discuss them in class to try and determine the most appropriate course of action (Newman \& Pollnitz 2001). Students can therefore be measured according to whether they made the 'right' decision. This is a common form of ethics education, borrowed from other professional fields such as business and clinical medicine. Gallagher (2013) refers to this as 'fast' ethics, in contrast to a kind of 'slow ethics' where a more relational, situated response is required. The 'fast' approach can be seen as relevant to these fields since the ethical dimension most commonly comes to the fore in relation to difficult intellectual decisions, whether regarding financial transparency or eliciting consent for surgery. In traditional professions such as law, medicine and business, it is therefore quite possible to act in a way that is ethically correct but to be impatient, judgemental, unkind and selfish. For practitioners who are role models for young children, extending 'professional love' to them (Page 2013), the conceptualisation of ethics must necessarily be very different, leading to a different kind of ethics education. The effects of 'fast' ethics in ECEC are clear. As I have tried to argue (Taggart, 2011), we are in danger of producing practitioners who do not value or understand the complexity of their own care simply because universities find it difficult to measure this. The basis for an alternative approach can be found in 'care ethics', used to refer to the work of feminist writers such as Gilligan (1982), Noddings (2003) and Tronto (1994) and which, rather than asking what is right and just in a universal sense, asks how we should respond in particular situations and to whom are we responsible. People are seen as inescapably relational, in varying degrees of dependence on one another.

Care ethics is ideally suited to the work of ECEC practitioners. This is because, although it is part of a philosophical tradition of 'moral sentimentalism' which emphasises the role 
(C) Geoff Taggart In Langford, R. (forthcoming) Theorising Feminist Ethics of Care in Early Childhood Practice: Possibilities and Dangers London: Bloomsbury

of feeling in ethical life, it is also part of a multi-disciplinary feminist tradition which celebrates holistic, embodied forms of knowledge and behaviour. The insights of care ethicists, for example, accord well with those of psychoanalytic feminists (e.g. Chodorow 1978; Hollway 2006) who trace the capacity to care back to the primordial needs and desires of infancy, producing a pleasing alignment between the standpoints of early childhood theory and those of care ethics. That is, in the same way that Piaget and Dewey demonstrated how our physical embodiment gives rise to our knowledge, challenging the dualism between body and mind, feminist approaches to morality similarly show how our ethical responsiveness arises out of our bodily life and its history and out of our inescapable relatedness.

Such an interdisciplinary framework for the forthcoming discussion, bringing together psychology and philosophy, is inspired by the work of Govrin (2014a; 2014b) who is concerned at the way in which care ethics, as a branch of moral philosophy, seems to be languishing in the academic backwaters. He explicitly seeks to ground it more firmly in human psychology, arguing that the adult moral sense is derived from ties of dependency in early childhood. His argument, drawn from Gray and Wegner (2009), rests on the insight that, despite their complexities, moral dilemmas in adulthood seem to be understood in terms of the same primary, dyadic schema (i.e. a moral 'agent' and a moral 'patient') as the mother-child interactions of infancy. Recalling Nodding's (2010) metaphor of primary attachment relationships as the 'incubator' of adult ethics, he argues that these schemas are foundational and that the strength and security of early attachment will condition adult morality. For Govrin, the essence of care ethics therefore lies in the importance of secure attachment to moral life.

So what might be the role of the university in preparing this kind of ethical professional whose ethics depends as much upon her psychological history as on her formal 
(C) Geoff Taggart In Langford, R. (forthcoming) Theorising Feminist Ethics of Care in Early Childhood Practice: Possibilities and Dangers London: Bloomsbury

intelligence? Most institutions which train preschool teachers entitle their programmes 'early childhood education and care'. Yet, although students are asked to reflect on and analyse how young children should be educated, they are rarely asked to reflect upon what it means to care for or about them. It is not as though practitioners are resistant to this. When given the opportunity, practitioners typically talk about professionalism and ethics in terms of love, care and empathy (e.g. Dalli 2008; Cousins 2015; Campbell-Barr et al. 2015; Davis and Degotardi 2015) yet this discourse is mostly absent from the training competences and policy documents which govern their work. I would argue that these failings occur partly because the history and structure of higher education is predicated upon an educated ideal which has never taken 'care' seriously and which cannot accommodate itself to the broader, more embodied epistemology and ethics represented by movements in feminism. There are isolated examples where the affective dimension of ethical life is addressed in training such as in the use of 'applied theatre' (Khaner and Linds 2015) or in videoing practice (Elicker et al. 2008; Biglan et al. 2013). However, the legacy of an entrenched model which defines what it means to be moral and educated is a significant challenge for those teaching graduate-level carers.

\section{Reflective practice and the 'educated ideal'}

Care is a holistic concept, bringing together thought and feeling, mind and body. Influential contributions to care ethics (e.g. Held 2006; Sevenhuijsen 1998) have sought to show that this holistic concept is basic to human experience because of our collective susceptibility to vulnerability and dependence. Therefore, care is not something we ever grow out of. In contrast, the hegemonic view of development, grounded in the triumph of Western science and reason, is that the role of care becomes progressively less as that of education increases and, in this way, education is assumed to be 'for' the achievement of self-sufficiency and autonomy (Van Laere et al 2014). Arguing that 
(C) Geoff Taggart In Langford, R. (forthcoming) Theorising Feminist Ethics of Care in Early Childhood Practice: Possibilities and Dangers London: Bloomsbury

human beings are as relational as they are autonomous and affective as they are cognitive, care ethics has been part of a broader feminist movement which has challenged assumptions about the nature of knowledge and education, particularly in relation to professional education.

In the 1980's, a cadre of feminist philosophers and psychologists interpreted intellectual history to explain the way in which a patriarchal norm of the 'educated man' had become hegemonic in higher education. Merchant (1980) showed how the arguments of Renaissance men such as Thomas Bacon were used to extol a mechanistic perspective on people and the environment, perpetuating Platonic conceptions of nature as feminine and ideas as masculine. Writers such as Lloyd (1984) and Schott (1988) demonstrated that the model of the 'good man', inherited from Kant, requires us to act purely from force of will rather than any natural feeling. The research of Gilligan (1982), which pioneered care ethics, was a reaction against the Kantian theory of moral stages which implied a natural and universal progression to moral abstraction and propositional moral reasoning, hallmarks of 'the educated ideal' (Roland 1981). Some writers took a Freudian view and saw in the attempt to 'reign in' the wild, disorderly and unpredictable realm of the natural world, a kind of 'reaction-formation' against the uncertainty represented by the loss of a organic, relational, medieval worldview. For example, Bordo (1987) perceived this kind of reaction-formation in Descartes' Meditations, the text which provides the basis for our assumption that thought is primary and the external world of the senses (including the body) is of secondary importance. Certainly, in the cultural upheaval that marked the dawn of modern science, it could be re-assuring to know that at least one's thoughts are true. Yet, at the same time, Cartesian dualism legitimised an educated mindset which pushed a wealth of human experience to the margins. Care ethicist Sara Ruddick $(1989,195)$ notes that 
(C) Geoff Taggart In Langford, R. (forthcoming) Theorising Feminist Ethics of Care in Early Childhood Practice: Possibilities and Dangers London: Bloomsbury

Cartesian reason has been idealised as 'active, autonomous, controlling, progressive and socially powerfully yet exempt from unwanted social responsibilities.' She contrasts this with the female experience of the birth process as 'incontinent, repetitiously irregular, insufficiently individuated and vulnerable to pain, confinement and onerous responsibility' and suggests that the idealisation of reason, stemming from Descartes, is a defensive reaction to human fragility. Bordo concludes her own analysis of Descartes' 'flight to objectivity' by contrasting his world of separate, atomised minds with the thenrecent findings of Gilligan and her celebration of empathy, closeness and connectedness as necessary features of human rationality.

Despite these challenges to an educated rationality and arguments to include care and moral emotions as knowledge, one could argue that it is not care ethics which has helped most to raise the intellectual legitimacy of qualitative knowing in the university. Instead, various kinds of phenomenology have offered alternatives to the rigid, Cartesian distinction between 'knower' and 'known' and have sought to show that care and relationship are inscribed at the heart of the human condition. Heidegger, for example, argued that the sheer fact of being 'thrown' involuntarily into existence and being alive ('Being') is a state that is ontologically fundamental and that care is intrinsic to it. The perspective is summarised well by Boff $(2007,15)$ :

That is, to care is at the very heart of the human being: it is there before anyone does anything... This means that we must acknowledge that the attitude of taking care is a fundamental mode of being which is always present and which cannot be removed from reality.

Care is also at the heart of Buber's (1970) phenomenology, reversing Descartes' famous dictum to become something akin to 'others exist, therefore I am'. Buber 
(C) Geoff Taggart In Langford, R. (forthcoming) Theorising Feminist Ethics of Care in Early Childhood Practice: Possibilities and Dangers London: Bloomsbury

contests the assumption that we can truly know ourselves in isolation and argues that it is only through the caring relation of 'I-Thou' that the self is fully completed and understood. Despite the intellectual impact of these theories, the phenomenology which has had the most impact upon reflective practice is that of Merleau-Ponty (1945). He proposes that a caring relationship rests on more than a collection of data about the subject: it is mediated via a web of subtle perceptions understood through the body. According to Merleau-Ponty, perception has a 'figure-ground' structure in the sense that, when we identify an object, we set it apart from the others in the perceptual field. The body participates in this process by becoming part of either the focal point (figure) or the background (ground). For example, when I cut my hand and put a plaster on it, it is the figure, when I use a pen or a knife, it is the ground. This movement in and out of focal attention explains how carers are able to offer an embodied presence to a client or patient whilst also temporarily effacing themselves. Hamington $(2004,50)$ argues that the idea of 'figure-ground interactions provides a useful way of framing Noddings' understanding of engrossment'. That is, engrossment involves being at least temporarily other-directed with one's own thoughts and perceptions relegated to the background. Yet important perceptual data, such as a child looking pale or feeling cold, will make themselves tacitly known to us in the background. Of equal importance is MerleauPonty's more esoteric metaphor of 'the flesh', communicating the insight that all human knowledge is grounded intersubjectively in our bodily perceptions. Human beings are both subject and object to each other, in the same way that, when I rub my hands together, they are touching and being felt simultaneously. This intersubjectivity provides a corporeal basis for an ethic of care. The relevance of these ideas to ECEC is suggested by Wynn (1997) who suggests that Winnicott's holding relationship is one in which the mother is 'held' and defined by the child in as much as it also occurs the other way round. 
(C) Geoff Taggart In Langford, R. (forthcoming) Theorising Feminist Ethics of Care in Early Childhood Practice: Possibilities and Dangers London: Bloomsbury

This radically intersubjective and embodied conception of the self underpins the discourse of reflective practice. This is usually seen as originating in the work of Schon (1983) which became a tool for professionalisation of teaching, nursing and social work in the 1980's and 90's. Schon was critical of the way in which professional knowledge was assumed to operate in the same way as scientific knowledge, according to objective principles which could be turned into rules. Such 'technical rationality', he argued, had become part of professional life because the established professions had consolidated their influence in the nineteenth century, at the high watermark of Enlightenment reason. To legitimise their status, doctors and lawyers had embraced a form of scientific method as their modus operandi. Yet it was clear to Schon that practitioners in caring professions did not work in such a way, applying disembodied principles to particular cases: the knowledge was far more situated and dialogical. In his famous metaphor, Schon proposed that, rather than viewing each case from the epistemological high ground, practitioners are obliged to enter the 'swampy lowlands' of practice, occupied by vulnerable, unpredictable clients. Particularly in nursing, professionalism has come to be seen as a commitment to reflective practice and a phenomenological approach to knowledge (e.g. Benner 1984). For example, Johns $(2009,3)$, argues that reflection 'is a critical and reflexive process of self-inquiry and transformation of being and becoming the practitioner you desire to be'. Self-awareness and emotional articulacy are emphasised and practitioners are encouraged to develop a phenomenological understanding of their presence and availability to clients and patients. Such an approach to ethical practice is diametrically opposed to the ethics of Kant who would argue that the very fact that an act is based on relationship rather than duty alone renders it unethical. Being a 'reflective practitioner' calls for more of a moral imagination than an awareness of duties and it is here where care ethics can make the best contribution, in articulating the phenomenological dynamics of compassionate 
(C) Geoff Taggart In Langford, R. (forthcoming) Theorising Feminist Ethics of Care in Early Childhood Practice: Possibilities and Dangers London: Bloomsbury

relations. For example, Benhabib (1987) demonstrates that knowledge about something seems to be a condition for care: the more we know about a person or subject discipline, the more we care about it. She argues that a key insight of care ethics is that the ethical impulse arises out of what we know in a tangible and intimate terms rather than in an abstract sense: there is a 'concrete other' rather than some universal, idealised other to whom we are meant to act ethically. Dunne (1998), in his discussion of practical judgement, describes such moral practice in terms first outlined by Aristotle. This embodied practice which requires discernment and wisdom he called 'phronesis' and contrasted it with 'techne', the practice of making things and producing outcomes. In the field of ECEC, rather than applying rules and principles to real-life situations, it is more plausible that practitioners, as with nurses and their patients, develop an ethical phronesis in the course of their interactions with parents and children. But what models of relationship does care ethics draw upon and how can they be applied to the work of practitioners?

\section{Mothering and empathy}

In the key texts of care ethics (e.g. Noddings 2003; Ruddick 1989), the figure of the mother is emblematic of the relational practice being described and the relevance of this to the in loco parentis position of early childhood teachers is clear. Noddings' examples, whether responding to a child's cries or teaching him to be gentle with the cat, centre on a dyadic interaction whereby the 'one caring' temporarily puts her own concerns to one side, becomes receptive to the needs of the 'cared for' and demonstrates a responsive availability to him. There is 'motivational displacement' (Noddings 2010, 48) in that the energy of the carer flows towards the 'cared for'. In order to be an act of caring, it has to be received and understood as such by the recipient. It is the experience of these acts of 'natural caring', exemplified most strongly 
(C) Geoff Taggart In Langford, R. (forthcoming) Theorising Feminist Ethics of Care in Early Childhood Practice: Possibilities and Dangers London: Bloomsbury

in mothering or being mothered, which we return to at an unconscious level when

responding (or not) to demands on our caring capacities which are less straightforward, such as when we see someone fall in the street. We carry within us our 'best picture of ourselves caring and being cared for' and, in encountering the stranger, 'I may reach towards the memory and guide my conduct by it if I wish to do so' (Noddings 2003, 8). Thus, mothering is the process by which ethical attitudes are cultivated and perpetuated across generations. This notion that early experience is the source of moral qualities would seem to be endorsed by no less a figure than the Dalai Lama, when pointing out the central importance of compassion:

Compassion fosters positive conditions for survival. As soon as we leave our mother's womb, the feeling of intimacy is key to survival and the proper development of our life. Immediately after birth, the young child is like a small animal. By nature, by biology, the child senses his survival depends entirely on affection. So the child seeks immediate connection with the mother. I think mother's milk is a symbol of compassion. (Dalai Lama and Chan 2012, 101)

In her study of 'maternal thinking', Ruddick (1989) similarly focusses on mothering as foundational in generating an experiential sense of all that is good. In particular, she focusses on the importance of story-telling in establishing trust and imparting a sense of robust identity to children:

Through good stories, mother and children connect their understandings of a shared experience. They come to know and, to a degree, accept each other through stories of the fear, love, anxiety, pride and shame they shared or provoked. Children are shaped by ... the stories they are first told. But it is also true that story-telling at its best enables children to adapt, edit and invent life stories of their own. (Ruddick 1989, 98) 
(C) Geoff Taggart In Langford, R. (forthcoming) Theorising Feminist Ethics of Care in Early Childhood Practice: Possibilities and Dangers London: Bloomsbury

Ruddick argues that the ethical sensitivity demonstrated by mothers needs to be celebrated and extended to build a 'politics of peace'.

Understandably, the attention given to mothering as the practice which is paradigmatic of care ethics has drawn criticism. Bowden $(1996,37)$, for example, refers to the gender essentialism which underpins the argument and the sense that a set of 'emotionally privileged, white, middle class mothering practices' are seen as representative of mothering in general. More importantly for the purposes of the current argument is that such an emphasis on mothering, despite the claim that men may also display these skills, does little to raise the professional standing of ECEC teachers beyond 'women's work'.

Building on the philosophical insights of David Hume, Engster (2015) suggests that care behaviour is not founded upon any particular social role but is more fundamental to our nature. He draws evidence from Darwinist theory, ethology and brain chemistry to propose that care ethics is a naturalistic philosophy, rooted in biology and psychology. More particularly, the evolutionary antecedents and biological markers of care behaviour can be seen to underpin the phenomenon of compassion, the empathic desire to alleviate the vulnerability or suffering of others. This is relevant to care work in ECEC (e.g. Taggart 2016; Rajala and Lipponen 2018) where practitioners routinely work empathically with vulnerable subjects.

Gilbert (2010) understands compassion as an outgrowth of the mammalian relationship of attachment and bonding, a relationship we instinctively look for as a kind of 'social mentality'. That is, as an archetypal structure of the mind, it guides the motive and feelings of care and cared-for in relation to each other, signals when caring is occurring and provides positive feedback to keep it going. Within this relationship, a particular 'affect regulation system' is vital, one that is often ignored. Gilbert observes that, firstly, 
(C) Geoff Taggart In Langford, R. (forthcoming) Theorising Feminist Ethics of Care in Early Childhood Practice: Possibilities and Dangers London: Bloomsbury

humans spend a lot of time pursuing, achieving and consuming in a driven way (an ' instinctive, reason-focussed system') or, secondly, protecting themselves in a fearful way ( a 'threat-focussed' system). Yet there is also a 'soothing/contentment' system that enables us to have a sense of wellbeing and of being at peace. The hormone oxytocin is triggered by the attachment bond, bringing feelings of softness and wellbeing. Gilbert articulates the heart of his argument:

Compassion arises from the balance of the three emotion systems. In particular, it operates through care-giving, social mentality that orients us to focus on alleviating distress and promoting flourishing. We now know that this social mentality has evolved with, and is linked to, the soothing contentment system.

(Gilbert 2010, 202)

The findings discussed above reveal that our moral capacity is more holistic than purely cognitive and that any programme of ethical development needs to adopt a similarly holistic approach. Care can be seen as hard-wired into our cell structure, such as in the 'mirror neurons' which fire in response to both one's own actions and responses and those of others, allowing a foundation for empathy. Yet, if this is the case, why are human beings so variable in their capacity for care and empathy and is this a capacity which professional education can address?

\section{Attachment style and capacity to care}

Early nurture provides clues to this variability, gained from research going back to the 1930 's. Prior to this time, psychologists understood an offspring's bond with the mother primarily in terms of the need for food. Yet Harlow's work with monkeys and substitute 'mothers' showed that, in fact, they preferred the softer, more comforting substitutes than the metal ones which provided the milk: emotional support seemed to be as 
(C) Geoff Taggart In Langford, R. (forthcoming) Theorising Feminist Ethics of Care in Early Childhood Practice: Possibilities and Dangers London: Bloomsbury

primary as nutrition (Harlow 1958). With a similar interest in biology, Bowlby (e.g. 1979)

theorised that the desire for proximity to the mother is a tool for evolutionary survival

and that, with a 'secure base', young children can become more confident and

exploratory. Yet it is not only the child's care-seeking which brings this about.

Ainsworth's studies (e.g. Ainsworth et al. 1978) showed that it is the quality of the

parent's care-taking behaviour which accounts for attachment security. Responsive

attunement to the child's needs is the determining factor. By contrast, stern,

authoritarian parenting seemed to produce insensitivity and excessive self-reliance

(avoidant attachment) in children. Vague, non-attuned and inconsistent parenting

seemed to prevent children from understanding themselves and acting authentically

(ambivalent attachment). The implications of these early attachments for moral

development were shown by Bowlby's own research into teenage criminals which

revealed the impact of 'maternal deprivation'.

Research over the last fifty years seems to corroborate the observation that the

attachment styles we form are predictive of how we act morally' (Music 2016, 253).

Toddlers with more secure attachment are more likely to act according to their

conscience and be more responsive and co-operative as they grow up (Kochanska et al.

2010). In contrast to toddlers with an experience of abuse, they are also more likely to

offer support if they hear another child in distress (Main and George 1985). As adults,

people with a history of secure attachment are more likely to make better life partners

(Kunce and Shaver 1994), to volunteer in the communities and to look after their own

elderly parents themselves (Gillath et al. 2005a), to be less susceptible to 'compassion

fatigue' (Tosone et al. 2010) and to be more inclined to find the selflessness of child-

rearing enjoyable (Volling et al. 1998). If they are leaders, they are also more likely to be thought of as fair and trustworthy (Popper et al. 2000). In Gilbert's language (2010), 
(C) Geoff Taggart In Langford, R. (forthcoming) Theorising Feminist Ethics of Care in Early Childhood Practice: Possibilities and Dangers London: Bloomsbury

secure individuals have a developed soothing/contentment system which allows them to feel safe enough to step outside their own perspective. Tsilika et al. (2015) note that caregivers with patterns of secure attachment are more able to give consistent emotional support to patients.

By contrast to these fortunate individuals, less positive attachment styles seem to compromise the capacity of individuals to act in altruistic, pro-social ways. Caregivers with insecure attachment find care-giving more stressful and are less altruistic in their motives (Nicholls et al. 2014). Avoidant adults can become perfectionist and workaholic (Mayseless 1996), are reluctant to appear vulnerable and are dismissive of vulnerability or distress (Scharf et al. 2004). Vachon $(2015,103)$ points out that care professionals with an avoidant attachment style are more likely to be 'good technicians' with a less developed interpersonal ethic of care. When avoidant adults become parents, the expectations placed upon them that they will be sensitive and responsive provoke unusual stress (Rholes et al. 2006) and the usual solution is to adopt a style that is either authoritarian or managerial since this kind of emotional defence helps to make caregiving manageable (Simpson et al. 1996; George and Solomon 2008; De Oliveira et al. 2005). In the typical case, such avoidance will reduce the individual's capacity for compassion, not only as it affects personal relationships but in reducing community or voluntary participation. On one hand, therefore, it may be unlikely that individuals with this pattern may choose to work with young children. On the other, avoidant adults may gain a significant amount of personal validation from their ability to control, predict and regulate the routines of those who are especially vulnerable. If practitioners with this pattern exist, they are therefore more likely to occupy managerial positions, perhaps preferring it to the messiness of 'being with the children'. 
(C) Geoff Taggart In Langford, R. (forthcoming) Theorising Feminist Ethics of Care in Early Childhood Practice: Possibilities and Dangers London: Bloomsbury

For adults with a contrasting, ambivalent style of attachment, pre-occupation with relationship extends into the workplace and their interest in love, care and support makes them ideal candidates for caring professions. Yet the realm of the personal is constantly in danger of overtaking the professional. Pre- occupied adults have high tendencies to self-disclosure, particularly on social media (Oldmeadow et al. 2013), and towards dramatizing relationships: friends and colleagues are referred to in sentimental terms and may receive extravagant gifts or displays of loyalty (Bauminger et al. 2009; Feeney 2004; Collins et al. 2004). Yet when these people develop their own interests or separate relationships (for example with workers in a different team or organisation), this can be experienced as abandonment. Relationships with children are similar. For such adults, children represent the possibility of full emotional availability: 'babies...hold out the longed for prospect of a relationship with someone who can be loved and who will return love without the fear of abandonment' (Howe 2011, 145). This kind of mother tends to 'act out' impulsive responses in a spontaneous, inconsistent way, showering children with affection and gifts one day and wearily dismissing them the next. Irritation is likely to emerge when babies or young children begin to explore their immediate environment with the mother's intervention: burgeoning independence returns the adult to a sense of her own loneliness and poor self-worth. The existence of early years practitioners with unfulfilled emotional needs would suggest the involvement of the pre-occupied style of attachment in this behaviour. For example, in her research, Osgood $(2012,76)$ concludes that, for some of her interviewees, 'becoming part of ECEC services was constructed as a form of cathartic reconciliation for the perceived shortcomings of their own childhoods.' Certainly, several researchers have concluded that, for disadvantaged young women, working in a nursery is a passage to acceptance and 'respectability' (Skeggs 1997; Colley 2006; Vincent and Braun 2010). 
(C) Geoff Taggart In Langford, R. (forthcoming) Theorising Feminist Ethics of Care in Early Childhood Practice: Possibilities and Dangers London: Bloomsbury

In the light of this overview, the relevance of psychological research in compassion to the work of ECEC practitioners is clear:

The ability to help others is a consequence of having witnessed and benefitted from good caregiving on the part of one's attachment figures, which promotes the sense of security as a resource and provides models of good caregiving. (Gillath, Shaver and Mikulincer 2005b, 9)

This could represent a rather fatalistic assessment. Apparently rigid and inflexible contrasts between different attachment styles might suggest that one's ethical capacity is predetermined through a combination of genes and environmental conditioning, allowing education and training little influence. I will argue that this is not the case.

\section{Morality and emotional awareness}

The argument I am making is that attachment security allows for greater perspectivetaking and empathy, key features of ethical life, and so a phenomenological approach to professional development will be necessary to help practitioners understand this. Yet, on first analysis, it would certainly seem that the idea of basing a moral theory on one's capacity for empathy is flawed. Even if we leave attachment styles out of the equation, empathy tends to falter in encounters with people perceived as outsiders (Xu, Zuo, Wang and Han 2009) or if empathy is seen as potentially dangerous or uncomfortable (e.g. Davis 1996). Altruism stalls if we feel fearful and isolated. These findings echo the insights of Hume that our capacity for 'universal sympathy' is weak and variable and underpin the arguments of psychologists such as Bloom (2018) who maintains, contrary to popular understanding, that empathy provides a very unhelpful basis for our ethical behaviour. He offers the example that, using our inherited capacity for empathy alone, we would be unfair and give preferential treatment to people with whom we feel a 
(C) Geoff Taggart In Langford, R. (forthcoming) Theorising Feminist Ethics of Care in Early Childhood Practice: Possibilities and Dangers London: Bloomsbury

natural affiliation. At first sight, reasoning and judicial reflection would seem to be the tools that, once again, we have to fall back on in order to act morally. Yet I would argue that the pessimism about 'universal sympathy' is unfounded. Certainly, we are more likely to respond to one person empathetically than a hundred, even though the hundred may be more deserving. But this pattern does not indicate that empathy itself is limited, only that people fear being overwhelmed by it because they wrongly believe their capacity is limited (Cameron 2013, 3).

Through organisations such as the Mind and Life Institute and the Greater Good Science Centre at UC Berkeley, there is increasing evidence that our capacity for care, empathy and compassion is like a muscle which can grow stronger through practice and 'that we can indeed train the brain to become more compassionate' (Davidson 2012, 118). This muscle may be underdeveloped as a result of our own early experience but it does not mean that it is lost or incapable of growth. In fact, the very belief that it can grow is likely to be a self-fulfilling prophecy. For example, Schumann et al. (2014) found that, if a person holds a 'mindset of empathy', in which the quality is seen as malleable and workable, they are more likely to expend greater empathic effort. Participants were offered persuasive evidence of either the fixed or malleable view of empathy: those who had been presented with the latter view were more likely to express greater willingness to be empathic over a serious disagreement. The researchers also found that those presented with the latter view spent longer listening to a personal story from someone in a different racial group and indicated that they would offer more hours volunteering in a cancer support group. The authors conclude that an effective way to cultivate moral emotions is to simply challenge the view that the capacity to have them is fixed and preset. In an objective sense, ethical characteristics certainly seem to be more adaptive and developmental than we thought. 
(C) Geoff Taggart In Langford, R. (forthcoming) Theorising Feminist Ethics of Care in Early Childhood Practice: Possibilities and Dangers London: Bloomsbury

A central practice in 'expanding the empathic bandwidth' (Cameron 2013, 1) is that of mindfulness, a secular form of present-moment, non-judgemental awareness found within most world religions but particularly within Buddhism. Originally popularised by Kabat-Zinn (1982) as a form of stress management, this practice aims to bring about this awareness by deliberately narrowing the field of attention, typically by becoming attentive to one's body and breathing. There have been a number of empiricallysupported effects of mindfulness which relate to prosocial behaviour, in particular better emotional regulation (e.g. Cahn and Pollich 2009; Goldin and Gross 2010). That is, by disidentifying from our habitual spontaneous reactions, we can be more patient or receptive to others and build a broader repertoire of ethical behaviours. For example, in one study (Birnie et al. 2010, 10), participants were shown to have 'a greater ability ot adopt others' perspectives, experienced reduced distress... and were increasingly spiritual and compassionate towards themselves.'

It is perhaps unsurprising that mindfulness has been shown to be effective in improving the quality of caring in work with vulnerable people and also in parenting (e.g. Duncan and Bardacke 2010; Coatsworth 2015). Goh (2012) discovered that mindful reflection helped social work students notice more readily when they were not listening to clients and Banks et al (2016) affirm the use of 'lovingkindness' practice to help professionals extend compassion to 'difficult' clients. Snyder, Shapiro and Treleaven (2012) suggest that the enhanced presence and availability of mindfulness practitioners makes the practice beneficial for caring professions. Studies involving parents have focussed on particularly challenging situations such as where children have mental health needs or are at risk of offending. In such intense circumstances, it is not difficult to appreciate how 'the parents' activity of simply slowing down enough to notice serves an empathic function' (Reynolds, 2003,10) 
(C) Geoff Taggart In Langford, R. (forthcoming) Theorising Feminist Ethics of Care in Early Childhood Practice: Possibilities and Dangers London: Bloomsbury

Despite these benefits, as Gilbert and Choden $(2013,138)$ point out, 'the secular mindfulness tradition has not worked with the cultivation of compassion in an explicit way'. They argue that mindfulness programs need to be presented within a framework of compassion in order to deal with the self-judgment, distraction and avoidance which are inevitable challenges. In other words, an attitude of compassion towards oneself is necessary first in order to engage mindfully and empathically with others. Engaging with the 'soothing/contentment' system bolsters self-acceptance and this is particularly useful in relation to insecure attachment. Mindful practice helps to reduce the stress it causes (Cordon et al. 2009) and self-compassion practice helps to cultivate and maintain the missing 'internal models' of attachment (Gilbert 2005; Siegel 2007). Intervention programmes designed to enhance compassion in general therefore typically involve exercises to boost compassion towards oneself, drawing upon the Buddhist notion of 'lovingkindness'. One exercise, for example, involves a guided visualisation to imaginatively recollect or create a compassionate, benevolent parent figure or mentor. These programmes have been positively evaluated in random controlled trials (e.g. Jazaieri et al. 2013) and have been shown empirically to increase compassionate, altruistic behaviour (Weng et al. 2013). As Music $(2017,256)$ observes, 'Ultimately, feeling safe, loved and cared for and not feeling too threatened opens up all kinds of possibilities for rich interaction and both empathic and altruistic acts.'

Such self-acceptance promotes the realisation of care ethics in practice. Vachon (2015, 103), for example, points out that increased self-compassion can help enhance secure attachment and foster patient, attentive care-taking. More generally, Moreira et al. (2015) argue that positive relationship with self seems to be a prerequisite for a caring, relational ethics, particularly with children. With these insights in mind, we can move on 
(C) Geoff Taggart In Langford, R. (forthcoming) Theorising Feminist Ethics of Care in Early Childhood Practice: Possibilities and Dangers London: Bloomsbury

to speculate about the kind of experiential, holistic pedagogy needed for ethical training in ECEC which can address the psychological roots of compassion.

\section{Contemplative pedagogy and reflective practice}

The discovery of mindfulness as a powerful intervention in learning and development has underpinned the emergence of contemplative pedagogy as a distinct field (Barbezat and Bush 2014; Ergas 2017; Sanders 2013; Lin et al. 2013.) This approach focusses on the incorporation of non-Western practices, including yoga, tai chi and walking mediation, into learning for the purposes of deepening insight and awakening ethical sensitivities. Significantly, in the light of the foregoing argument, it espouses a strongly phenomenological approach to knowledge. Roeser et al (2014), for example, contrast the 'dualistic meta-model of human development' opposing knower and known, mind and body, with a dialectical model in which the apparent opposites are synthesised. Contemplative pedagogy has had an influence upon the training of teachers (Bai et al. 2009; Kozik-Rosebal 2001; Miller and Ayako 2005; Mayes 1998; London 2013), building upon the insight of Palmer (1998) that 'we teach who we are'. It has also influenced the training of nurses (e.g. Watson 2009). Trainees may engage in creative writing using Jungian archetypes to understand their identity as teachers or practice group exercises to develop their presence and authenticity: however, the core practice is that of mindfulness. The avowedly therapeutic intentions of this contemplative approach to professional learning are mirrored in the psychoanalytical tradition of ECEC practitioner training, typified by the Tavistock Institute with its roots in the work of Winnicott and Bion. Elfer (2014) has drawn upon this tradition to pilot an approach to 'work discussion' for ECEC practitioners in which they can articulate the emotional challenges of attachment-based practice. In a safely contained space, practitioners consider how their own attachment styles and patterns of emotional defence may inhibit their caring 
(C) Geoff Taggart In Langford, R. (forthcoming) Theorising Feminist Ethics of Care in Early Childhood Practice: Possibilities and Dangers London: Bloomsbury

practices. Similarly, Emmett's $(2011,328)$ intervention showed that 'the inclusion of material about personal attachment history...strengthens the capacity of the participant to operationalise attachment-focussed practice.'

The common theme in both contemplative and psychoanalytic approaches is a radical deepening of the phenomenological reflective practice, discussed earlier. Rather than an artificial technique which a practitioner may draw upon, the aspiration is that reflection will become more of a 'special quality of being' (Johns 2009,3 ) so that one will develop the habit of 'living out of reflective practice' (Watson 2009, viii). I would argue that mindfulness practice can promote this goal since it helps us to 'unhook from autopilot' (Lombard et al. 2017, p83) and become more aware of our judgements and actions. According to Watson $(2009, \mathrm{x})$, a 'personal wisdom practice' brings the values and dispositions of the nurse to the fore which then, in turn, inform the discipline of professional caring: 'the wisdom of reflective moral knowing combines with one's inner energy and the radiance of love, beauty, compassion and human presence.'

In both psychoanalytic and contemplative contexts, the pedagogic process involves 'clearing a space for care' (Wilde 2013, 74) with a high priority placed on listening. A secure holding space is established with clear time limits and the minimum necessary direction is applied to the discussion. The pedagogic style is facilitative, with participants given the opportunity to articulate and explain their experiences. Elfer (2014) explains how, inasmuch as the participants discussed dealing with breaches of procedure or staff personal issues, the relatively loose structure allowed for silence to emerge between contributions and that the participants gradually became more comfortable with it. This open and bounded structure is mirrored in the Courage to Teach model of professional development (Palmer 1998) which draws upon the Quaker tradition of a 'clearness 
(C) Geoff Taggart In Langford, R. (forthcoming) Theorising Feminist Ethics of Care in Early Childhood Practice: Possibilities and Dangers London: Bloomsbury

committee.' The focus of the group stays with the experience of a particular participant, rather than moving back and forth. As a trainer in the process comments:

They are fully present to the person and his or her issue, listening deeply, creating a space of deep respect. The function of the committee is not to 'fix' or give advice but to help the focus person hear her own inner wisdom, claim her own authority (to literally be the author of her own story. (Hare 2014, 61)

With this in mind, participants are only allowed to reply to the speaker in the form of open, honest questions: a meditative, reflective atmosphere is maintained.

In my own experience (Taggart 2015), I endeavour to structure a safe, collaborative space as part of a module on 'the professional self' in ECEC. Mindful compassion is introduced as part of a session on attachment relationships. Students are given supervision scenarios to role play and to reflect upon in terms of what they reveal about the character's attachment styles. For their assessment, they reflect upon their abilities as leaders and carers and write an assignment based on research into 'professional love' they carried out in their settings. Evaluations of the module are often very personal and disclose how the experience has deepened their confidence in the ethical value of their practice.

Within programmes such as this, an altruistic commitment to attentive and supportive care of young children can be cultivated and sustained through regular and mindful exercises in which students place embodied attention on their natural reservoirs of kindness, benevolence and compassion. By cultivating self-acceptance, practitioners can soften defences, relax habitual attachment styles and offer greater emotional availability and caring to children. As Siegel $(2010,86)$ observes, 'just as our attunement to our children promotes a healthy, secure attachment, tuning into the self also 
(C) Geoff Taggart In Langford, R. (forthcoming) Theorising Feminist Ethics of Care in Early Childhood Practice: Possibilities and Dangers London: Bloomsbury

promotes a foundation for resilience and flexibility'. The persuasiveness of his argument may be reason why, in 2013 , the Zero to Three organisation held a US symposium which described the integration of mindfulness into a university-based, state-wide infant mental health program (Clark, Gilkerson and Shahnoon-Shanok 2013).

\section{Conclusion}

Returning to the vignette with which we started, one can more easily understand that professional state of mind and heart which Renee brings to the interaction. She has slowed down her mind so that, rather than racing into the future, it is focussed on the child in front of her, a state of engrossment. Rather than oblige the child to act and respond in ways which address her own unmet needs, she remains open and available. Her ethical skill, based on a phenomenological awareness of mind and body together, challenges the foundations of conventional ethics education. As Dirkx (2008) points out:

Sustaining the ethic of the social contract implicit in professionalism requires more than a technical or rational understanding of the rules and values inherent in such a contract. Commitment to this ethic arises fundamentally from a deep sense of self, from attention to less conscious and visible forces brewing from within. Ultimately, doing the right thing within a professional role is derived from an awareness of and deep connection with these inner forces.

Early childhood teachers are engaged on a daily basis with children who are at a formative stage in developing an attachment style and they appreciate the need to work affectively and sensitively with them so that they can grow up to become well-adjusted, pro-social adults. Yet, if higher education is to take a role in the ethical preparation of practitioners for caring professions, it will need to embrace a more holistic pedagogy. If the pedagogy envisaged here can become more commonplace, these teachers may recognise that, along with our concepts and schemas of knowledge, our adult ethical habits also stem from early 'internal models' and that we can develop these habits deliberately by building and fuelling the compassionate heart of these models. In this 
(C) Geoff Taggart In Langford, R. (forthcoming) Theorising Feminist Ethics of Care in Early Childhood Practice: Possibilities and Dangers London: Bloomsbury

way, compassionate teachers will be able to foster a compassionate heart in the children they serve.

7715 words

\section{References}

Ainsworth, M.D., Blehar, M.C., Waters, E. and Wall, S.N. 1978. Patterns of Attachment: a Psychological Study of the Strange Situation. London: Routledge

Bai, H., Scott, C. and Donald, B. 2009. "Contemplative Pedagogy and the Revitalisation of Teacher Education." Alberta Journal of Educational Research 55 (3): 319-334

Banks, B., Burch, T. and Woodside, M. 2016." Introducing Mindfulness and Contemplative Pedagogy as an Approach to Building Helping Skills in Human Services Students". Journal of Human Services (Fall/2016): 47-60 
(C) Geoff Taggart In Langford, R. (forthcoming) Theorising Feminist Ethics of Care in Early Childhood Practice: Possibilities and Dangers London: Bloomsbury

Barbezat, D. and Bush, M. 2014. Contemplative Practices in Higher Education San Francisco: Jossey-Bass

Bauminger, N., Finzi-Dottan, R., Chason, S. and Har-Even, D. 2009. "Intimacy in Adolescent Friendship: the Roles of Attachment, Coherence and Self-disclosure." Journal of Social and Personal Relationships 25 (3): 409-28

Benhabib, S. 1987. "The Generalised and Concrete Other: the Kohlberg-Gilligan Controversy and Moral Theory." In Women and Moral Theory, edited by Kittay, E.F. and Meyer, D.T., 154-177 London: Rowman and Littlefield.

Benner, P. 1984. From Novice to Expert: Excellence and Power in Clinical Nursing Practice. NY: Pearson

Biglan, A., Layton, G.L., Jones, L.B. Hankins, M. and Rusby, J.C. 2013. "The Value of Workshops on Psychological Flexibility for Early Childhood Special Education Staff." Topics in Early Childhood Special Education 32 (4): 196-210

Birnie, K. Speca, M. and Carbon, L.E. 2010. “Exploring Self-compassion and Empathy in the Context of Mindfulness-based Stress Reduction (MBSR)". Stress and Health 26 (5): $359-371$

Bloom, P. 2018. Against Empathy: the Case for Rational Compassion. London: Vintage Boff, L. 2007. Essential Care: an Ethics of Human Nature Waco, TX: Baylor University Press

Bordo, S. 1987. The Flight to Objectivity: Essays on Cartesianism and Culture Albany, NY: SUNY Press 
(C) Geoff Taggart In Langford, R. (forthcoming) Theorising Feminist Ethics of Care in Early Childhood Practice: Possibilities and Dangers London: Bloomsbury

Bowden, P. 1996. Caring: Gender-Sensitive Ethics. London: Routledge

Bowlby, J. 1979. The Making and Breaking of Affectional Bonds. London: Tavistock

Buber, M. 1970. I-Thou. NY: Simon and Schuster

Cahn, B.R. and Pollich, J. 2012. "Meditation and the P3a Event-related Brain Potential." International Journal of Psychophysiology 72: 51-60

Cameron, C.D. (2013) Can you run out of empathy?

https://greatergood.berkeley.edu/article/item/run out of empathy [accessed Feb 2018]

Campbell-Barr, V., Georgeson, J. \& Varga A. N. 2015. “Developing Professional Early Childhood Educators in England and Hungary: Where Has All the Love Gone?" European Education, 47, pp. 311-330.

Chodorow, N. 1978. The Reproduction of Mothering: Psychoanalysis and the Sociology of Gender. Berkeley, CA: University of California Press

Clark, R., Gilkerson, L. and Shahmoon-Shanok, R. 2013. "Integrating Mindfulness Within Training, Supervision, and Practice With Parents and Young Children". Conference Presentation ZERO TO THREE 2013 - 28th National Training Institute, December 12th 2013, San Antonio Texas

Coatsworth, J.D., Duncan, L.G., Nix, R.L., Greenberg, M.T., Gayles, J.G., Banberger, K.T., Berrens, E. and Demi, M.A. 2015. “Integrating Mindfulness with Parent Training: Effects of the Mindfulness-enhanced Strengthening Families Program." Developmental Psychology 51 (1): 26-35 
(C) Geoff Taggart In Langford, R. (forthcoming) Theorising Feminist Ethics of Care in Early Childhood Practice: Possibilities and Dangers London: Bloomsbury

Colley, H. 2006. "Learning to Labour with Feeling: Class, Gender and Emotion in Childcare, Education and Training." Contemporary Issues in Early Childhood 7, no. 1: 1529.

Collins, N.C., Guichard, A.C.,Ford, M.B. and Feeney, B.C. 2004. "Working Models of Attachment: New Developments and Emerging Themes." In Adult Attachment: Theory, Research and Clinical Implications, edited by W.S. Rholes and J.A. Simpson, NY: Guilford Press

Cordon, S.L., Brown, K.W. and Gibson, P.R. 2009. "The Role of Mindfulness-based Stress Reduction on Perceived Stress: Preliminary Evidence for the Moderating Role of Attachment Style". Journal of Cognitive Psychotherapy 23 (3): 258-268

Cousins, S. 2015. "Practitioners' Constructions of Love in the Context of Early Childhood Education and Care: A Narrative Inquiry." PhD diss. University of Sheffield.

Dahlberg, G., and P. Moss. 2005. Ethics and Politics in Early Childhood Education. London: Routledge

Dalai Lama and Chan, V. 2012.The Wisdom of Compassion. NY: Bantam Press

Dalli, C. 2008. “Pedagogy, Knowledge and Collaboration: Towards a Ground-up Perspective on Professionalism." European Early Childhood Education Research Journal 16 (2): 171-185

Davidson, R.J. 2012. "Toward a Biology of Positive Affect and Compassion." In Visions of Compassion: Western Scientists and Tibetan Buddhists Examine Human Nature, edited by Davidson, R.J. and Harrington, A. , 107-130 Oxford: Blackwell

Davis, M. (1996) Empathy: a social psychological approach. Boulder: Westview. 
(C) Geoff Taggart In Langford, R. (forthcoming) Theorising Feminist Ethics of Care in Early Childhood Practice: Possibilities and Dangers London: Bloomsbury

Davis, B. and Degotardi, S. 2015. “Who cares? Infant Educators' Responses to Professional Discourses of Care." Early Childhood Development and Care 185 (11-12):

$1733-1747$

DeOliveira, C.A.,Moran, G. and Pederson, D.R. 2005. “Understanding the Link Between the Maternal Adult Attachment Classifications and Thoughts and Feelings about Emotions." Attachment and Human Development 7 (2): 153-70

Dirkx, J.M. 2008. “Care of the Self: Mythopoetic Dimensions of Professional Preparation and Development." In Pedagogies of the Imagination edited by Leonard, T and Willis, P. Amsterdam:Springer

Duncan, L. and Bardacke, N. 2010. “Mindfulness-based Childbirth and Parenting Education: Promoting Family Mindfulness During the Perinatal Period." Journal of Child and Family Studies 19 (2):190-202

Dunne, J. 1998. Back to the Rough Ground: Practical Judgement and the Lure of Technique. Notre Dame, IN: University of Notre Dame Press

Elfer, P. 2014. "Facilitating intimate and thoughtful attention to infants and toddlers in nursery" In Lived Spaces of Infant-Toddler Education and Care: International Perspectives on Early Childhood Education and Development 11, edited by Harrison, L.J. and Sumsion, J., 103-107 Amsterdam: Springer

Elicker, J., Georgescu, O. and Bartsch, E. 2008. “Increasing the Sensitivity of Childcare Providers: Applying the Video-Feedback Intervention in a Group Setting." In Promoting Positive Parenting: an Attachment-Based Intervention edited by Juffer, F., BakermansKranenberg, M.J. and Van ljzendorn, M.H London: Lawrence Erlbaum 
(C) Geoff Taggart In Langford, R. (forthcoming) Theorising Feminist Ethics of Care in Early Childhood Practice: Possibilities and Dangers London: Bloomsbury

Emmett, S. 2011. “Preparing Professional Caregivers as Young Children's Attachment Partners: a Longitudinal Study of a New Australian Pre-service Program." Phd diss.

University of Melbourne

Engster, D. 2015. "Care in the State of Nature". In Care Ethics and Political Theory edited by Engster, D.and Hamington, M. Oxford: OUP

Ergas, O. 2017. “Reclaiming 'Self' in Teachers' Images of Education Through Mindfulness as Contemplative Inquiry." Journal of Curriculum and Pedagogy 14 (3): 218-235

Feeney, J.A 2004. “Adult Attachment and Relationship Functioning Under Stress Conditions" In Adult Attachment: Theory, Research and Clinical Implications edited by W.S. Rholes and J.A. Simpson NY:Guilford Press

Feeney, S. and Freeman, N. 2018. Ethics and the Early Childhood Educator: Using the NAEYC Code [Third Edition] Washington DC: NAEYC

Fennimore, B.S. 2014. Standing Up for Something Every Day: Ethics and Justice in Early Childhood Classrooms. NY: Teachers College Press

Gallagher, A 2013. "Slow Ethics: a Sustainable Approach to Ethical Care Practices?" Clinical Ethics 8 (4): 98-104

George, C. and Solomon, J. 2008. "The Caregiving System: a Behavioural Systems Approach to Parenting." In Handbook of Attachment: Theory, Research and Clinical Applications, edited by Cassidy, J. and Shaver, P.R. London: Guilford Press

Gilbert, P. 2010. The Compassionate Mind. London: Constable 
(C) Geoff Taggart In Langford, R. (forthcoming) Theorising Feminist Ethics of Care in Early Childhood Practice: Possibilities and Dangers London: Bloomsbury

Gilbert, P. and Choden 2013. Mindful Compassion: Using the Power of Mindfulness and Compassion to Transform our Lives. London: Constable

Gillath, O., Shaver, P.R., Mikulincer, M., Nitzberg, R.E., Erez, A. and Van Ijzendoorn, M.H. 2005a. “Attachment, Caregiving, and Volunteering: Placing Volunteerism in an Attachment-Theoretical Framework." Personal Relationships 12 (4): 425-446

Gillath, O., P. R. Shaver, and M. Mikulincer. 2005b. “An Attachment-Theoretical Approach to Compassion and Altruism." In Compassion: Its Nature and Use in Psychotherapy, edited by P. Gilbert, 121-147. London: Routledge

Gilligan, C. 1982. In a Different Voice: Psychological Theory and Women's Development. Cambridge, MA: Harvard University Press

Goh, E.C. L. 2012. "Integrating Mindfulness and Reflection in the Teaching and Learning of Listening Skills for Undergraduate Social Work Students in Singapore." Social Work Education 31 (5): 587-604

Goldin, P.R. and Gross, J.J. 2010. “Effects of Mindfulness-based Stress Reduction (MBSR) on Emotion Regulation in Social Anxiety Disorder." Emotion 10 : 83-91

Govrin, A. 2014a. "The ABC of Moral Development: an Attachment Approach to Moral Judgement." Frontiers in Psychology 5 (6): 1-15

Govrin A. 2014b." From Ethics of Care to Psychology of Care: Reconnecting Ethics of Care to Contemporary Moral Psychology." Frontiers in Psychology 5: 1-10

Gray, K. and Wegner, D. 2009. "Moral Typecasting: Divergent Perceptions of Moral Agents and Moral Patients'. Journal of Personality and Social Psychology 96: 505-520 
(C) Geoff Taggart In Langford, R. (forthcoming) Theorising Feminist Ethics of Care in Early Childhood Practice: Possibilities and Dangers London: Bloomsbury

Hamington, M. 2004. Embodied Care: Jane Addams, Maurice Merleau-Ponty and Feminist Ethics Chicago: University of Illinois Press

Hare, S.Z. 2013. "What is the Clearness Committee?" In Let the Beauty We Love Be What We Do: Stories of Living Divided No More, edited by Hare, S.Z. and LeBouttillier, M. Pawleys Island, SC: Prose Press

Harlow, H. F. 1958. "The Nature of Love." American Psychologist 13, 673-685

Held, V. 2006. The Ethic of Care: Personal, Political and Global Oxford: OUP

Hollway, W. 2006. The Capacity to Care: Gender and Ethical Subjectivity. London:

Routledge

Howe, D. 2011. Attachment across the Lifecourse. London: Palgrave

Jazaieri, H., Jinpa, G.T., McGonigal, K., Rosenberg, E.L., Finkelstein, J. Simon-Thomas, E. , Cullen, M., Doty, J.R., Gross, J.J. and Goldin, P.R. 2013. “Enhancing Compassion: a Randomised Controlled Trial of a Compassion-Cultivation Training Programme." Journal of Happiness Studies 14 (4): 1113-1126

Johns, C. 2009. Becoming a Reflective Practitioner [3 $3^{\text {rd }}$ edition]. Oxford: Blackwell Kabat-Zinn, J. 1982. “An Outpatient Program in Behavioural Medicine for Chronic Pain Patients Based on the Practice of Mindfulness Meditation." General Hospital Psychiatry 4: $33-47$

Khaner, T. and Linds, W. 2015. "Playing in Entangled Spaces: Exploring Ethical Know-how through Embodied Inquiry" In Playing in a House of Mirrors: Applied Theatre and Reflective Practice, edited by Vettraino, E. and Linds, W. Amsterdam: Sense Publications 
(C) Geoff Taggart In Langford, R. (forthcoming) Theorising Feminist Ethics of Care in Early Childhood Practice: Possibilities and Dangers London: Bloomsbury

Kochanska, G. et al. 2010. "Positive Socialisation Mechanisms in Secure and Insecure Parent-Child Dyads: Two Longitudinal Studies." Journal of Child Psychology and Psychiatry 51 (9): 998-1009

Kozik-Rosabal, G.S. 2001. "How do They Learn to be Whole? A Strategy for Helping Preservice Teachers Develop Dispositions" In Unfolding Bodymind: Exploring Possibility Through Education, edited by Hocking, B., Haskell, J. and Linds, W. Brandon, VT: Foundation for Educational Renewal

Kunce, L. J., and P. R. Shaver. 1994. "An Attachment-Theoretical Approach to Caregiving in Romantic Relationships." In Attachment Processes in Adulthood Advances in Personal Relationships, edited by K. Bartholomew and D. Perlman, 205-237. London: Jessica Kingsley,

Langford, R. Richardson, B., Albanese P., Bezanson K., Prentice S. and White J. 2017. "Caring about Care: Reasserting Care as Integral to Early Childhood and Care Practice, Politics and Policies in Canada." Global Studies of Childhood 7 (4): 311-322

Lin, J., Oxford, R.L. and Brantmeier, E.J. eds. 2013. Re-envisioning Higher Education: Embodied Pathways to Wisdom and Social Transformation. Charlotte, NC: Information Age

Lloyd, G. 1984. The Man of Reason: 'Male' and 'Female' in Western Philosophy London: Routledge

Lombard, K., Horton-Deutsch, S. and Davies, A. 2017. “Creating Space for Reflection: the Importance of Presence in the Teaching-Learning Process" In Reflective Practice: Transforming Education and Improving Outcomes, edited by Horton-Deutsch, S. and Sherwood, G.D. Indianapolis: Sigma Theta Tai International 
(C) Geoff Taggart In Langford, R. (forthcoming) Theorising Feminist Ethics of Care in Early Childhood Practice: Possibilities and Dangers London: Bloomsbury

London, R. 2013. "Transformative Approaches to Teacher Education: Becoming Holistic Educators in 'Unholistic' Settings" In Re-envisioning Higher Education: Embodied Pathways to Wisdom and Social Transformation, edited by Lin J., Oxford, R.L. and Brantmeier, E.J. (eds.) Charlotte, NC: Information Age

Main, M. and George, C. 1985. "Responses of Abused and Disadvantaged Toddlers to Distress in Agemates: a Study in the Daycare Setting." Developmental Psychology 21 (3): $407-412$

Mayes, C. 1998. "The Use of Contemplative Practices in Teacher Education." Encounter: Education for Meaning and Social Justice 11 (3): 17-31

Mayseless, O. 1996. "Attachment Patterns and Their Outcomes." Human Development 36: $206-33$

Merchant, C. 1980. The Death of Nature: Women, Ecology and the Scientific Revolution. London: Harper Collins

Merleau-Ponty, M. 1945. The Phenomenology of Perception. London: Routledge

Mikulincer, M., O. Gillath, Y. Sapir-Lavid, E. Yaakobi, K. Arias, L. Tal-Aloni, and G. Bor.

2003. "Attachment Theory and Concern for Others' Welfare: Evidence that Activation of the Sense of Secure Base Promotes Endorsement of Self-Transcendence Values." Basic and Applied Social Psychology 25: 299-312.

Mikulincer, M., and P. R. Shaver. 2001. "Attachment Theory and Intergroup Bias: Evidence that Priming the Secure Base Schema Attenuates Negative Reactions to Outgroups." Journal of Personality and Social Psychology 81: 97-115. 
(C) Geoff Taggart In Langford, R. (forthcoming) Theorising Feminist Ethics of Care in Early Childhood Practice: Possibilities and Dangers London: Bloomsbury

Miller, J.P. and Ayako, N. 2005. "Contemplative Practices in Teacher Education."

Encounter: Education for Meaning and Social Justice 18 (1): 42-48

Moss, E.E., Hirshberg, M.J., Flook, L. and Graue, M.E. 2017. Cultivating reflective teaching practice through mindfulness. In Impacting Teaching and Learning:

Contemplative Practice, Pedagogy and Research in Education, edited by Dorman, E.H., Byrnes, K. and Dalton, J. London: Rowman and Littlefield

Moreira, H., Gouveia, M.J., Carona, C., Silva, N. and Canavarro, M.C. 2015. “Maternal Attachment and Children's Quality of Life: the Mediating Role of Self-Compassion and Parenting Stress." Journal of Child and Family Studies 24: 2332-2344

Music, G. 2016. Nurturing Natures: Attachment and Children's Emotional, Sociocultural and Brain Development [ $2^{\text {nd }}$ edition]. London: Routledge

Newman, L. and Pollnitz, L. 2001. “Helping Students Make Tough Decisions Wisely: the Challenge of Ethical Inquiry." Australian Journal of Early Childhood 26 (4): 39-46

Nicholls, W., Hulbert-Williams, N. and Bramwell, R. 2014. "The Role of Relationship Attachment in Psychological Adjustment to Cancer in Patients and Caregivers: a Systematic Review of the Literature." Psychoimmunology 23: 1083-1095

Noddings, N. 2003 Caring: A Feminine Approach to Ethics. London: University of California Press

Noddings, N. 2010. The Maternal Factor: Two Paths to Morality Berkeley, CA: University of California Press

Oldmeadow, J.A., Quinn, S. and Kowert, R. 2013. "Attachment Style, Social Skills, and Facebook Use Amongst Adults." Computers in Human Behaviour 29: 1142-1149 
(C) Geoff Taggart In Langford, R. (forthcoming) Theorising Feminist Ethics of Care in Early Childhood Practice: Possibilities and Dangers London: Bloomsbury

Osgood, J. 2012. Narratives from the Nursery: Negotiating Professional Identities in Early Childhood London: Routledge

Page, J. 2013. "Permission to love them.... but not too much." In Working with Babies and Children: From birth to three (2nd Edn) edited by Page, J. Clare, A. and Nutbrown, C., 192-196 London: Sage.

Page, J. 2015. "Constructions of Intimacy in Early Childhood Education and Care: practitioners' experiences." http://professionallove.group.shef.ac.uk [accessed March 2018]

Palmer, P. 1998. The Courage to Teach: Exploring the Inner Landscape of a Teacher's Life. SF: Jossey-Bass

Popper, M. Mayesless, O. and Castelnovo, O. 2000. "Transformational Leadership and Attachment." The Leadership Quarterly 11 (2): 267-289

Rajala, A., and Lipponen, L. 2018. “Early Childhood Education and Care in Finland:

Compassion in Narrations of Early Childhood Education Student Teachers." In International Perspectives on Early Childhood Education and Care: Early Childhood Education in the $21^{\text {st }}$ Century Vol I, edited by S. Garvis, S.Phillipson, \& H. HarjuLuukkainen, 64-75 London: Routledge

Reynolds, D. 2013. “Mindful Parenting: a Group Approach to Enhancing Reflective Capacity in Parents and Infants." Journal of Child Psychotherapy 29 (3): 357-374 Rholes, W.S., Simpson, J.A. and Friedman, M. 2006. “Avoidant Attachment and the Experience of Parenting." Personality and Social Psychology Bulletin 32 (3): 275-285 
(C) Geoff Taggart In Langford, R. (forthcoming) Theorising Feminist Ethics of Care in Early Childhood Practice: Possibilities and Dangers London: Bloomsbury

Roeser, R.W. Vago, D.R. and Pinela, C, 2014. “Contemplative Education: Cultivating Ethical Development through Mindfulness Training" In Handbook of Moral and Character Development, edited by Nucci, L., Krettenauer, T. and Narvaez, D. London: Routledge

Roland, J. 1981. "The Ideal of the Educated Person." Educational Theory 31 (2): 97-109.

Ruddick, S. 1989. Maternal Thinking: Towards a Politics of Peace NY: Beacon Press Sanders, L. 2013. Ed. Contemplative Studies in Higher Education Special issue: New Directions for Teaching and Learning Issue 134. NY: Wiley

Scharf, M., Mayseless, O. and Kivenson-Baron, I. 2004. “Adolescent Attachment Representations and Development Tasks in Emerging Adulthood." Developmental Psychology 40 : 430-44

Schott, R.M. 1988. Cognition and Eros: a Critique of the Kantian Paradigm. NY: Beacon Press

Schon, D.A. 1983. The Reflective Practitioner: How Professionals Think in Action. NY: Basic Books

Schumann, K., Zaki, J. and Dweck, C.S. 2014. "Addressing the Empathy Deficit: Beliefs about the Malleability of Empathy Predict Effortful Responses when Empathy is Challenging." Journal of Personality and Social Psychology 107 (3): 475-493 Sevenhuijsen, S. 1998. Citizenship and the Ethics of Care: Feminist Considerations on Justice, Morality, and Politics London: Routledge Siegel, D.J. 2007. The Mindful Brain: Reflections and Attunement in the Cultivation of Well-being. NY: WWNorton 
(C) Geoff Taggart In Langford, R. (forthcoming) Theorising Feminist Ethics of Care in Early Childhood Practice: Possibilities and Dangers London: Bloomsbury

Simpson, J.A., Rholes, W.S. and Philips, D. 1996. "Conflict in Close Relationships: an

Attachment Perspective." Journal of Personality and Social Psychology 71 (5): 899-914

Skeggs, B. 1997. Formations of Class and Gender. London: Sage

Snyder R., Shapirio, S. and Treleaven, D. 2011. "Attachment Theory and Mindfulness." Journal of Child and Family Studies 21: 709-717

Taggart, G. 2011. “Don't We Care?: The Ethics and Emotional Labour of Early Years Professionalism." Early Years: An International Journal of Research and Development 31(1): 85-95.

Taggart, G. 2015. “Sustaining Care: Cultivating Mindful Practice in Early Years Professional Development." Early Years: An International Journal of Research and Development 35:4, 381-393

Taggart, G. 2016. “Compassionate Pedagogy: Ethics of Care in Early Childhood Professionalism." European Early Childhood Education Research Journal 24 (2): 173-185

Tosone, C., J. E. Bettmann, T. Minami, and R. A. Jasperson. 2010. “New York City Social Workers After 9/11: Their Attachment, Resiliency, and Compassion Fatigue." International Journal of Emergency Mental Health 12 (2): 103-116.

Tsilika, E., Parpa, E, Zygogianni, A, 2015. “Caregivers' Attachment Patterns and Their Interactions with Cancer Patients' Patterns." Supportive Care in Cancer 23: 87-94

Tronto, J. 1994. Moral Boundaries: Towards a Political Ethic of Care. London: Routledge

Vachon, M. 2015. "Targeted Intervention for Family and Professional Caregivers:

Attachment, Empathy and Compassion." Palliative Medicine 30 (2): 101-103 
(C) Geoff Taggart In Langford, R. (forthcoming) Theorising Feminist Ethics of Care in Early Childhood Practice: Possibilities and Dangers London: Bloomsbury

Van Laere, K.Vandenbroeck, M and Roets, G. 2014. "Challenging the Feminisation of the Workforce: Rethinking the Mind-Body Dualism in Early Childhood Education and Care." Gender and Education 26: 232-245

Vincent, C. \& Braun, A. 2010. “'And Hairdressers are Quite Seedy ...': the Moral Worth of Childcare Training." Contemporary Issues in Early Childhood 11(2), 204-214.

Volling, Brenda L;Notaro, Paul C;Larsen, Joelle J 1998. “Adult Attachment Styles:

Relations with Emotional Well-being, Marriage, and Parenting." Family Relations Oct 47:

4

Watson, J. 2009. "A Meta-Reflection on Reflective Practice and Where it Leads." In Transforming Nursing through Reflective Practice, edited by Johns, C. and Freshwater, D. Oxford: Blackwell

Weng, H., A. S. Fox, A. J. Shackman, D. E. Stodola, J. Z. K. Caldwell, M. C. Olson, G. M. Rogers, and R. J. Davidson. 2013. “Compassion Training Alters Altruism and Neural Responses to Suffering." Psychological Science. doi:0956797612469537

Wilde, S. 2013. Care in Education: Teaching with Understanding and Compassion. London: Routledge

Wynn, F. 1997. "The Embodied Chiasmic Relationship of Mother and Infant." Human Studies 20 (2): 253-270

Xu, X, Zuo, X. Wang, X and Han, S. 2009. "Do You Feel my Pain? Racial Group Membership Modulates Empathic Neural Responses." Journal of Neuroscience 29 (26): 8525-8529 
(C) Geoff Taggart In Langford, R. (forthcoming) Theorising Feminist Ethics of Care in Early Childhood Practice: Possibilities and Dangers London: Bloomsbury 